\title{
Experimental Study on Crimped Steel Fiber Reinforced Concrete Deep Beam in Shear
}

\author{
Mr. Vikram Vijaysinh Balgude ${ }^{1}$ \\ (Civil Department, Vidya Pratishthans College of Engineering / Pune University, India)
}

\begin{abstract}
The experimental work is carried out to evaluate the shear strength of steel fiber reinforced concrete deep beams without stirrups. For this 18 beams are cast. The beams are tested under two-point loading as per IS after 28 days curing. Fiber fraction is varied as $0 \%, 1.5 \%$ and $3 \%$. The shear span-to-depth ratio (a/d ratio) for beams is kept as 0.60 for specimen series-I and 0.74 specimen series-II. The cube compressive strength is estimated. The experimental results are compared with theoretical results obtained from empirical equations and design codes. Also the experimental results are compared with the equations put forth by the other researchers and codes to estimate the shear strength of the steel fiber reinforced concrete deep beams without stirrups.
\end{abstract}

Keywords: Crimped steel fiber, Deep Beam without shear reinforcement, Shear Strength, Ultimate Shear strength, Shear span to depth ratio

\section{INTRODUCTION}

The Deep beams are structural elements loaded as simple beams in which a significant amount of the load is carried to the supports by a compression force combining the load and the reaction. A deep beam is a beam having a depth comparable to the span length. According to Indian Standard provisions, deep beam is a beam having clear span to overall depth ratio less than 2.0 for simply supported beam and 2.5 for continuous beam. Reinforced concrete deep beams have many applications in building structures such as transfer girders, wall footings, foundation wall caps, floor diaphragms, and shear walls. Continuous deep beams occur as transfer girders in multi-story frames. Particularly, the use of deep beams at the lower levels in tall buildings for both residential and commercial purposes has increased rapidly because of their convenience and economical efficiency. The effect of steel fiber in concrete depends on type of steel fiber, aspect ratio (length-to-diameter ratio) of steel fiber and orientation of fibers in concrete. The strength of deep beams with normal amount of longitudinal reinforcement is usually governed by shear, not flexure. The shear strength of SFRC deep beams depends on different parameters such as type of steel fibers, aspect ratio of fibers, percentage longitudinal reinforcement, $a / d$ ratio and amount of fibers. The addition of small discrete steel fibers into the concrete mix helps to improve the post cracking tensile strength of hardened concrete and hence, significantly enhances the shear strength of reinforced concrete deep beams.

Many reports published over the past decades, confirm the effectiveness of steel fibers as shear reinforcement. Fibers are used to boost the shear capacity of concrete or to replace, in part, the vertical stirrups in reinforced concrete structural members, which reduce reinforcement congestion. But, shear strength of deep beams is highly influencing character. The great number of parameters that affect the beam strength has led to a limited understanding of shear failure. These parameters include fiber volume fraction, type of fiber, aspect ratio, size effect, percentage web reinforcement, a/d ratio, properties of concrete and steel. It is necessary to know the exact effect of addition of different fiber volume fraction and different shear span-to-depth ratio on shear strength of deep beam. Such an evaluation is needed for designing code which will recognize the contribution of steel fibers to the shear strength of reinforced concrete beams.

\section{INDENTATIONS AND EQUATIONS}

Six design equation, namely, the ACI Code 318-05, the UK's CIRIA Guide-2, Draft Eurocode-2, Mansur et al. equation, Londhe's equation and Khuntia et al. equation are used to estimate the ultimate shear strength of the deep beam specimens.

\subsection{ACI 318 [28] Design Model (2005)}

The shear provisions apply to both simple and continuous beams when the span to depth ratio is less than 5. The calculations are carried out for the critical section, which is defined as follows. The ACI code assumes that $V_{c}$ is equal to the shear strength of a beam without stirrups, which in turn, is taken equal to the load at which inclined cracking occurs, is calculated as:

The shear strength beam without stirrups can be computed as follows, In S.I. system ( $\mathrm{N}$, mm system) 
Where,

$$
V_{c}=\left(3.5-2.5 \frac{M_{u}}{V_{u}}\right)\left(0.16 \sqrt{f^{\prime}{ }_{c}}+17 \rho \frac{V_{u} \mathrm{~d}}{M_{u}}\right) \mathrm{bd}
$$

$M_{u}$ and $V_{u}$ are the ultimate moment and shear at the section under consideration.

$f^{\prime}{ }_{c}$ is the concrete compressive strength in $\mathrm{MPa}$,

$\rho$ is the longitudinal reinforcement ratio

$\left(A_{s} / b d\right)$ and $A_{s}$ is the area of longitudinal reinforcement.

\subsection{CIRIA Guide-2 [29] Design Model (1977)}

\subsubsection{Flexural Strength}

Capacity of the concrete section is as follows,

$$
M_{u}=0.12 f_{c u} \mathrm{bd}^{2}
$$

Area of main longitudinal reinforcement,

$$
\mathrm{A}_{\mathrm{s}}=M_{u} / 0.87 f_{y} \mathrm{z}
$$

Where,

$M_{u}=$ Ultimate moment,

$f_{y}=$ Steel characteristic strength,

$\mathrm{z}=$ Lever arm, which is to be taken as follows,

$$
\mathrm{z}=0.2 l+0.4 \mathrm{~d}, \text { for single span beams. }
$$

$\mathrm{z}=0.2 l+0.3 \mathrm{~d}$, for continuous beams

\subsubsection{Shear Strength}

The CIRIA Guide applies to beams having an effective span-to-depth ratio of less than 2 for single span beams and less than 2.5 for continuous beams. The CIRIA Guide- 2 method is applicable for the range of $0.5 \leq$ $a / d$ ratio $\leq 01.25$. Ultimate shear strength of deep beam without stirrups is,

$$
V_{c}=\lambda\left[\left(1-0.30 \frac{\mathrm{a}}{\mathrm{d}}\right) \sqrt{f_{c u}} \mathrm{bd}\right] .
$$

Where,

$V_{c}=$ Shear strength of concrete beam without stirrups

$\lambda=0.44$ for normal weight aggregates,

$f_{c u}=$ Compressive strength, $\mathrm{N} / \mathrm{mm}^{2}$,

$\mathrm{a}=$ Shear span,

$\mathrm{b}$ and $\mathrm{d}=$ Width and effective depth of beam.

\subsection{R. S. Londhe's [22] Proposed Equation (2011)}

The proposed equation of shear capacity of deep beam without shear reinforcement is as follows

$$
V_{c}=\alpha\left[\left(1-0.30 \frac{\mathrm{a}}{\mathrm{d}}\right) \sqrt{0.80 f_{c k}} \mathrm{bd}\right] .
$$

Where,

$V_{c}=$ Shear strength of deep beam without shear reinforcement

$\alpha=$ Empirical coefficient for concrete.

$f_{c k}=$ Characteristics compressive strength of concrete, $\mathrm{N} / \mathrm{mm}^{2}$

$\mathrm{b}$ and $\mathrm{d}=$ Width and effective depth of beam

$\mathrm{a}=$ Shear span

\subsection{Draft Eurocode-2 [30] Design Model (1984)}

The Draft Euro code applies to simply supported beams of span-to-depth ratio (L/D) less than 2 and to continuous beams of span-to-depth ratio (L/D) less than 2.5.

\subsubsection{Flexural Strength: Simply Supported Deep Beams}

The area of longitudinal reinforcement is calculated as follows

$$
\mathrm{A}_{\mathrm{s}}=\mathrm{M} /\left(f_{y} / \gamma_{m}\right)
$$

Where,

$\mathrm{M}$ is the largest applied bending moment in the span,

$f_{y}$ is the reinforcement characteristic strength,

$\gamma_{m}$ is the partial safety factor for material and 
$\mathrm{z}$ is the lever arm which is to be taken as follows

$$
\begin{array}{ll}
\mathrm{z}=0.2(\mathrm{~L}+2 \mathrm{D}) & \text { for } 1<(\mathrm{L} / \mathrm{D})<2 \\
\mathrm{z}=0.6 \mathrm{~L} & \text { for }(\mathrm{L} / \mathrm{D})<1 \ldots \ldots \ldots
\end{array}
$$

\subsubsection{Shear Strength}

The shear strength of beam without shear reinforcement is given as follows

$$
V_{c}=0.10 \mathrm{bD}\left(\frac{f^{\prime} c}{\gamma_{m}}\right)
$$

Where,

$\mathrm{b}$ is the width,

$\mathrm{D}$ is the beam depth,

$f^{\prime}{ }_{c}$ is the characteristic compressive strength of concrete and

$\gamma_{m}$ is a partial safety factor for material.

\subsection{Khuntia et al. [16] Proposed Equation (1999)}

As far as shear strength is concerned, the major difference between the reinforced concrete (RC) beams containing no fibers and those containing fibers lies in the significant post-cracking tensile strength of FRC. Therefore, it is rational to infer that the parameters influencing the ultimate shear strength of FRC beams are those that affect the shear strength of conventional RC beams plus the post-cracking tensile strength of FRC.

The shear strength of FRC is governed by the concrete contribution in the shear without stirrups and contribution of fibers. The shear strength FRC is given as follows

Where,

$$
V_{f r c}=\left(0.167 \alpha_{1}+0.25 \mathrm{~F}\right) \sqrt{f^{\prime} c} \mathrm{bd}
$$

$V_{f r c}=$ Shear strength of FRC,

$\alpha_{1}=2.5(\mathrm{~d} / \mathrm{a})$,

$\mathrm{F}=V_{f} \frac{l_{f}}{d_{f}}$,

$V_{f}=$ Fiber volume fraction,

$l_{f}=$ Length of fiber,

$d_{f}=$ Diameter of fiber,

$\mathrm{b}$ and $\mathrm{d}=$ Width and effective depth of beam,

$\mathrm{a}=$ Shear span

\subsection{Mansur et al. [2] Proposed Equation (1986)}

The equation proposed by Mansur et al. for shear strength of FRC is follows

$$
V_{f r c}=\left(0.16 \sqrt{f^{\prime} c}+17.2 \rho \frac{\mathrm{d}}{\mathrm{a}}+0.41 \tau \mathrm{F}\right) \mathrm{bd} .
$$

Where,

$f^{\prime} c=$ Characteristic compressive strength of concrete,

$\rho=$ Longitudinal reinforcement ratio,

$\mathrm{b}$ and $\mathrm{d}=$ Width and effective depth of beam,

$\mathrm{a}=$ Shear span,

$\mathrm{F}=V_{f} \frac{l_{f}}{d_{f}}$,

$V_{f}=$ Fiber volume fraction,

$l_{f}=$ Length of fiber,

$d_{f}=$ Diameter of fiber,

\section{FIGURES AND TABLES}

\subsection{Shear Test on Beam Specimen}

After 28 days curing period, the test beam specimens were removed from the curing tank and both sides of the beam were white-washed to aid observations of the crack development during testing. The beams were tested to failure under gradually increasing load in a Universal Testing Machine (UTM). The capacity of 
Universal Testing Machine (UTM) is of $1000 \mathrm{KN}$. A dial gauge was fixed at the bottom of beam to measure the mid-span deflection. Fig 1 shows the schematic arrangement of beam in UTM.

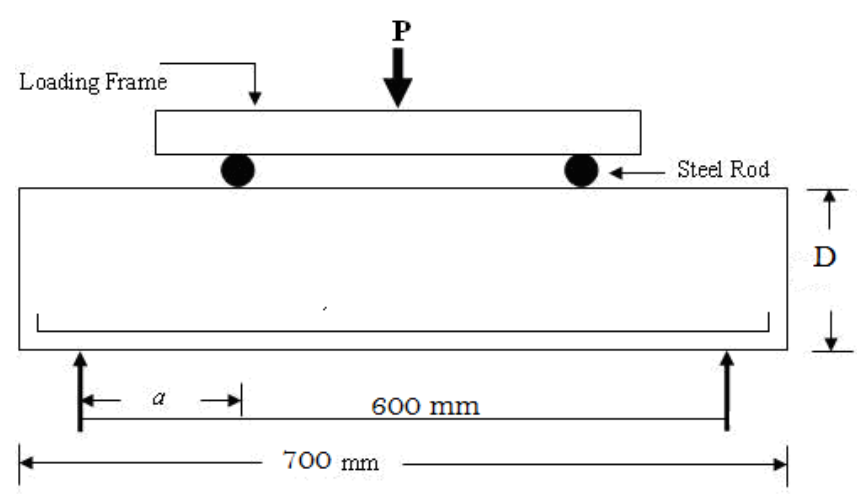

\subsection{Beam notations}

Fig 1: Beam Specimen under UTM

Total 18 simply supported deep beams were tested up to failure. All beams of specimen series-I were of rectangular cross-section, $90 \mathrm{~mm}$ wide and $360 \mathrm{~mm}$ deep having clear span of $600 \mathrm{~mm}$. Two bars of $16 \mathrm{~mm}$ diameter and two bars of $12 \mathrm{~mm}$ diameter were provided as longitudinal reinforcement. Grade of longitudinal reinforcement is Fe-500. Shear span-to-depth ratio is kept as 0.60 for all beams of specimen series-I. The fiber volume fraction varies as $0 \%, 1.5 \%$ and $3 \%$. For each fiber volume fraction 3 beams were casted. In the notation of all beams of specimen series I and II, series number is given first; this is followed by beam number then fiber volume fraction and then $a / d$ ratio. The details of test beam of series-I which content $0 \%$ fiber is given in Fig 2

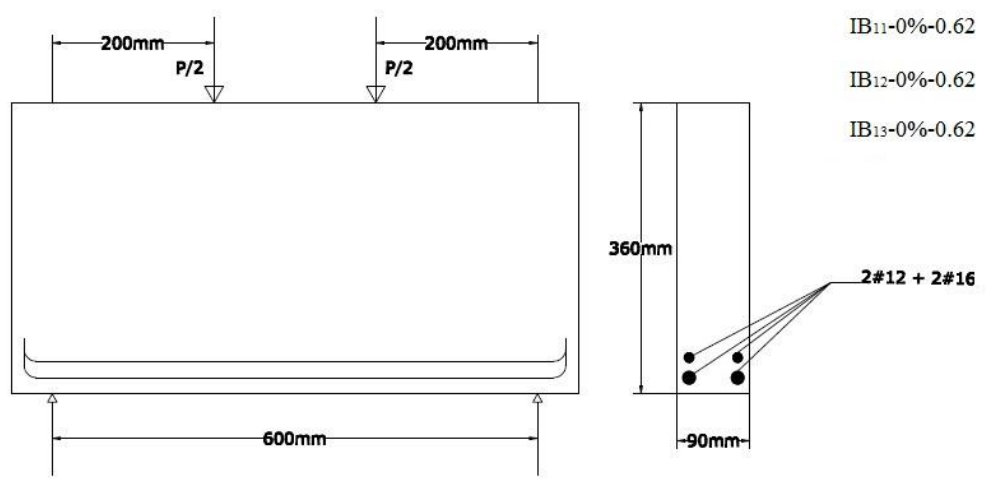

Fig 2: Details of Test Beam of Series-I which Content $0 \%$ Fiber

The details of test beam of series-I which content $1.5 \%$ fiber is given in Fig 3

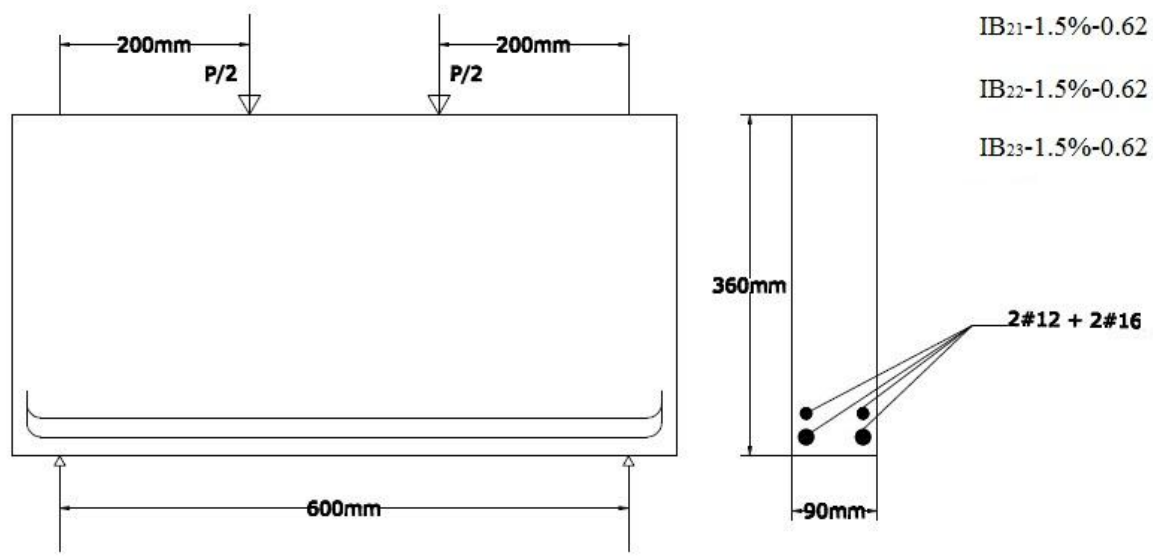

Fig 3: The Details of Test Beam of Series-I which Content $1.5 \%$ Fiber

The details of test beam of series-I which content $3 \%$ fiber is given in Fig 4 


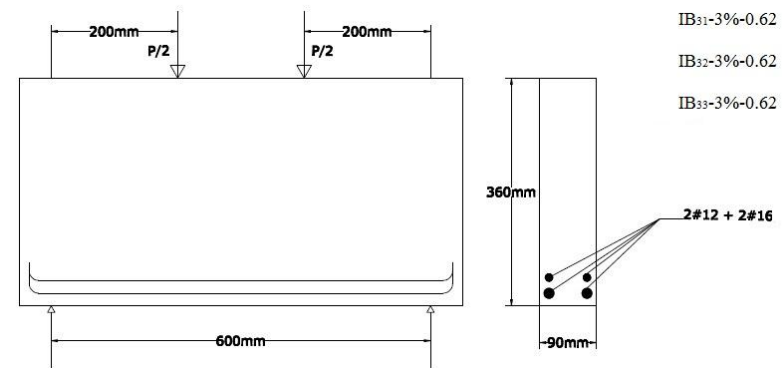

Fig 4: The Details of Test Beam of Series-I which Content $3 \%$ Fiber

All beams of specimen-II series were of rectangular cross-section, $90 \mathrm{~mm}$ wide and $330 \mathrm{~mm}$ deep having clear span of $600 \mathrm{~mm}$. Two bars of $16 \mathrm{~mm}$ diameter and one bars of $12 \mathrm{~mm}$ diameter were provided as longitudinal reinforcement. Shear span-to-depth ratio ( $a / d$ ratio) is kept as 0.74 for all beams of specimen-II series. The fiber volume fraction varied as $0 \%, 1.5 \%$ and $3 \%$. For each fiber volume fraction 3 beams were casted. In the notation of all beams of specimen series-II, series number is given first; this is followed by beam number then fiber volume fraction and then $a / d$ ratio. The details of test beam of series-II which content $0 \%$ fiber is given in Fig 5

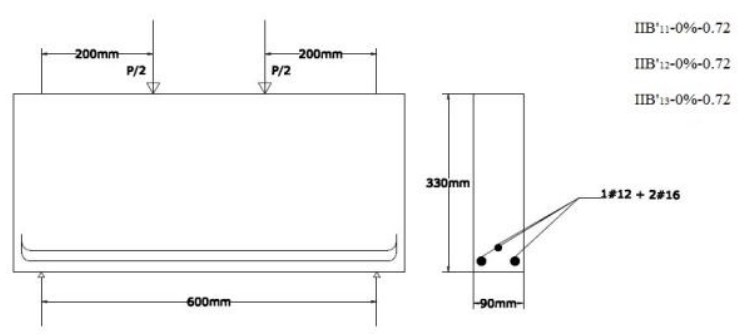

Fig 5: The Details of Test Beam of Series-II which Content $0 \%$ Fiber The details of test beam of series-II which content $1.5 \%$ fiber is shown in Fig 6

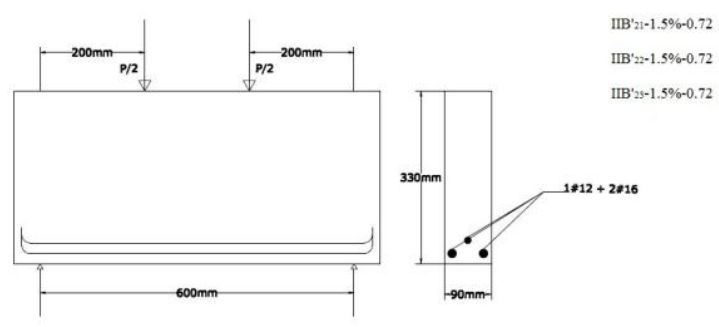

Fig 6: The details of test beam of series-II which content $1.5 \%$ fiber The details of test beam of series-II which content $3 \%$ fiber is shown in Fig 7

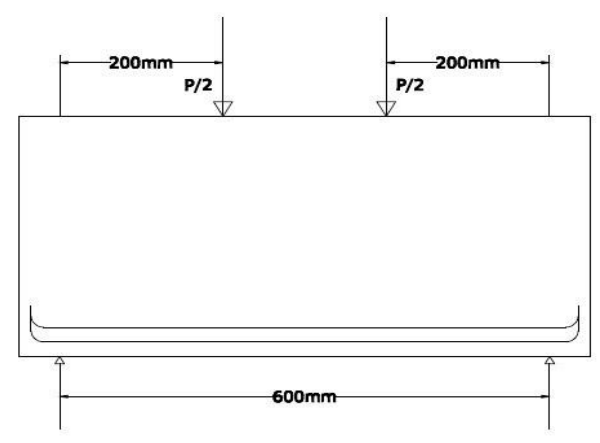

IIB' $31-3 \%-0.72$ IIB' $32-3 \%-0.72$ IIB' ${ }_{33-3 \%-0.72}$

Fig 7: The details of test beam of series-II which content $3 \%$ fiber 


\subsection{Cube Compressive Strength}

The results of cube compressive strength for specimen series-I after 28 days curing are obtained and are presented in Table 1.

Table 1: Compressive Strength of Concrete for Specimen Series-I, N/mm 2

\begin{tabular}{|c|c|c|c|c|}
\hline Sr. No. & Cube Designation & \% Fiber Content & $\begin{array}{c}\text { Cube Compressive } \\
\text { Strength } \\
\left(\mathbf{N} / \mathbf{m m}^{2}\right)\end{array}$ & $\begin{array}{c}\text { Average Cube } \\
\text { Compressive } \\
\text { Strength } \\
\left(\mathrm{N} / \mathbf{m m}^{2}\right) \\
\end{array}$ \\
\hline 1. & $\mathrm{C}_{11}$ & \multirow{3}{*}{0} & 45.70 & \multirow{3}{*}{46.99} \\
\hline 2. & $\mathrm{C}_{12}$ & & 47.85 & \\
\hline 3. & $\mathrm{C}_{13}$ & & 47.42 & \\
\hline 4. & $\mathrm{C}_{21}$ & \multirow{3}{*}{1.5} & 48.72 & \multirow{3}{*}{50.01} \\
\hline 5 . & $\mathrm{C}_{22}$ & & 50.44 & \\
\hline 6. & $\mathrm{C}_{23}$ & & 50.87 & \\
\hline 7. & $\mathrm{C}_{31}$ & \multirow{3}{*}{3} & 51.73 & \multirow{3}{*}{51.30} \\
\hline 8. & $\mathrm{C}_{32}$ & & 50.87 & \\
\hline 9. & $\mathrm{C}_{33}$ & & 51.30 & \\
\hline
\end{tabular}

The maximum value of compressive strength is $51.30 \mathrm{~N} / \mathrm{mm}^{2}$ and it is obtained for $3 \%$ fiber content.

The results of cube compressive strength for specimen series-II after 28 days curing are obtained and are presented in Table 2.

Table 2: Compressive Strength of Concrete for Specimen Series-II, N/mm²

\begin{tabular}{|c|c|c|c|c|}
\hline Sr. No. & Cube Designation & $\%$ Fiber Content & $\begin{array}{c}\text { Cube Compressive } \\
\text { Strength } \\
\left(\mathrm{N} / \mathbf{m m}^{2}\right)\end{array}$ & $\begin{array}{c}\text { Average Cube } \\
\text { Compressive } \\
\text { Strength } \\
\left(\mathrm{N} / \mathrm{mm}^{2}\right)\end{array}$ \\
\hline 1. & $\mathrm{C}_{11}^{\prime}$ & \multirow{3}{*}{0} & 46.56 & \multirow{3}{*}{47.52} \\
\hline 2. & $\mathrm{C}_{12}^{\prime}$ & & 48.28 & \\
\hline 3. & $\mathrm{C}_{13}^{\prime}$ & & 47.42 & \\
\hline 4. & $\mathrm{C}_{21}^{\prime}$ & \multirow{3}{*}{1.5} & 50.87 & \multirow{3}{*}{50.44} \\
\hline 5. & $\mathrm{C}_{22}^{\prime}$ & & 51.30 & \\
\hline 6. & $\mathrm{C}_{23}^{\prime}$ & & 49.15 & \\
\hline 7. & $\mathrm{C}_{31}^{\prime}$ & \multirow{3}{*}{3} & 51.73 & \multirow{3}{*}{50.87} \\
\hline 8. & $\mathrm{C}_{32}^{\prime}$ & & 50.01 & \\
\hline 9. & $\mathrm{C}_{33}^{\prime}$ & & 50.87 & \\
\hline
\end{tabular}

The maximum value of compressive strength is $50.87 \mathrm{~N} / \mathrm{mm}^{2}$ and it is obtained for $3 \%$ fiber content. It is observed from Table 1 and Table 2 that the compressive strength of concrete increases with increase in percentage fiber content, but there is not much more increase in compressive strength for $3 \%$ fiber content when compared to $1.5 \%$ fiber content.

\subsection{Central Deflection of Beams}

3.4.1 Central Deflection of Beam Specimen Series-I

Results of central deflection of beam specimen series-I are presented in Table 3.The graph of central deflection with respect to load is presented in Fig 8.

Table 3: Results of Central Deflection for Beam Specimen Series-I, mm

\begin{tabular}{|c|c|c|c|c|c|c|}
\hline \multirow[b]{2}{*}{ Sr. No. } & \multicolumn{2}{|c|}{ 0\% Fiber Content } & \multicolumn{2}{|c|}{ 1.5\% Fiber Content } & \multicolumn{2}{|c|}{ 3\% Fiber Content } \\
\hline & $\begin{array}{l}\text { Load } \\
(\mathrm{KN})\end{array}$ & $\begin{array}{l}\text { Deflection } \\
(\mathbf{m m})\end{array}$ & $\begin{array}{l}\text { Load } \\
(\mathrm{KN})\end{array}$ & $\begin{array}{l}\text { Deflection } \\
(\mathrm{mm})\end{array}$ & $\begin{array}{l}\text { Load } \\
(\mathrm{KN})\end{array}$ & $\begin{array}{l}\text { Deflection } \\
\quad(\mathrm{mm})\end{array}$ \\
\hline 1 & 0 & 0.00 & 0 & 0.00 & 0 & 0.00 \\
\hline 2 & 20 & 0.03 & 20 & 0.00 & 20 & 0.00 \\
\hline 3 & 40 & 0.08 & 40 & 0.07 & 40 & 0.05 \\
\hline 4 & 60 & 0.12 & 60 & 0.14 & 60 & 0.12 \\
\hline 5 & 80 & 0.16 & 80 & 0.20 & 80 & 0.20 \\
\hline 6 & 100 & 0.21 & 100 & 0.28 & 100 & 0.27 \\
\hline 7 & 120 & 0.24 & 120 & 0.35 & 120 & 0.34 \\
\hline 8 & 140 & 0.27 & 140 & 0.41 & 140 & 0.39 \\
\hline 9 & 160 & 0.32 & 160 & 0.45 & 160 & 0.46 \\
\hline 10 & 180 & 0.38 & 180 & 0.50 & 180 & 0.52 \\
\hline
\end{tabular}


Experimental study on crimped steel fiber reinforced deep beam in shear

\begin{tabular}{|c|c|c|c|c|c|c|}
\hline 11 & 200 & 0.44 & 200 & 0.53 & 200 & 0.58 \\
\hline 12 & 220 & 0.52 & 220 & 0.57 & 220 & 0.60 \\
\hline 13 & 240 & 0.61 & 240 & 0.61 & 240 & 0.74 \\
\hline 14 & 260 & 0.70 & 260 & 0.67 & 260 & 0.78 \\
\hline 15 & 264 & 0.78 & 280 & 0.71 & 280 & 0.84 \\
\hline 16 & & & 300 & 0.77 & 300 & 0.87 \\
\hline 17 & & & 320 & 0.82 & 320 & 0.91 \\
\hline 18 & & & 340 & 0.90 & 340 & 0.95 \\
\hline 19 & & & & & 360 & 1.01 \\
\hline 20 & & & & & 380 & 1.07 \\
\hline 21 & & & & & 384 & 1.10 \\
\hline
\end{tabular}

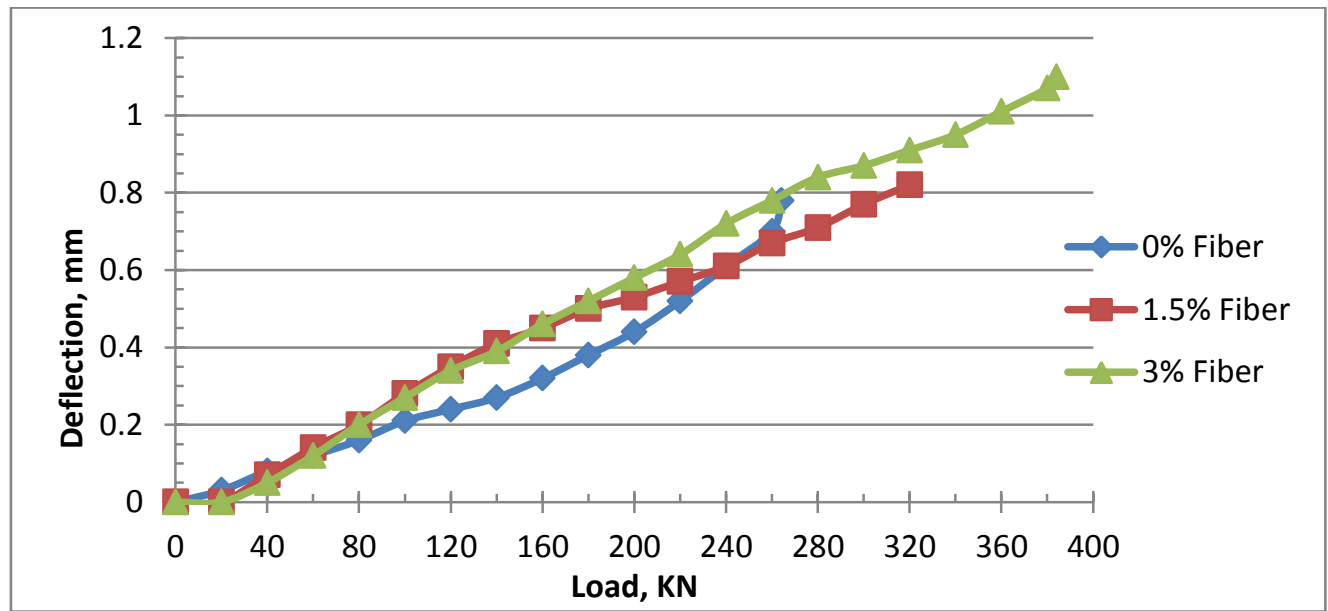

Fig 8: The Graph of Central Deflection with respect to Load, Specimen-I

From Table 3 and Fig 8 it is observed that, deflection increases with increase in fiber content.

\subsubsection{Central Deflection of Beam Specimen Series-II}

Results of central deflection of beam specimen series-II are presented in Table 4 and the graph of central deflection with respect to load is presented in Fig 9.

Table 4: Results of Central Deflection of Beam Specimen Series-II, mm

\begin{tabular}{|c|c|c|c|c|c|c|}
\hline & \multicolumn{2}{|c|}{ 0\% Fiber Content } & \multicolumn{2}{|c|}{ 1.5\% Fiber Content } & \multicolumn{2}{|c|}{ 3\% Fiber Content } \\
\hline Sr. No. & $\begin{array}{l}\text { Load } \\
(\mathrm{KN})\end{array}$ & $\begin{array}{l}\text { Deflection } \\
(\mathrm{mm})\end{array}$ & $\begin{array}{l}\text { Load } \\
\text { (KN) }\end{array}$ & $\begin{array}{c}\text { Deflection } \\
(\mathrm{mm})\end{array}$ & $\begin{array}{l}\text { Load } \\
(\mathrm{KN})\end{array}$ & $\begin{array}{l}\text { Deflection } \\
(\mathrm{mm})\end{array}$ \\
\hline 1 & 0 & 0.00 & 0 & 0.00 & 0 & 0.00 \\
\hline 2 & 20 & 0.8 & 20 & 0.00 & 20 & 0.00 \\
\hline 3 & 40 & 0.18 & 40 & 0.07 & 40 & 0.06 \\
\hline 4 & 60 & 0.24 & 60 & 0.15 & 60 & 0.12 \\
\hline 5 & 80 & 0.29 & 80 & 0.20 & 80 & 0.18 \\
\hline 6 & 100 & 0.35 & 100 & 0.26 & 100 & 0.23 \\
\hline 7 & 120 & 0.41 & 120 & 0.32 & 120 & 0.30 \\
\hline 8 & 140 & 0.46 & 140 & 0.37 & 140 & 0.35 \\
\hline 9 & 160 & 0.52 & 160 & 0.43 & 160 & 0.40 \\
\hline 10 & 180 & 0.58 & 180 & 0.47 & 180 & 0.46 \\
\hline 11 & 200 & 0.65 & 200 & 0.55 & 200 & 0.52 \\
\hline 12 & 201 & 0.71 & 220 & 0.63 & 220 & 0.57 \\
\hline 13 & & & 240 & 0.71 & 240 & 0.74 \\
\hline 14 & & & 260 & 0.79 & 260 & 0.83 \\
\hline 15 & & & 262 & 0.85 & 280 & 0.93 \\
\hline 16 & & & & & 298 & 1.01 \\
\hline
\end{tabular}




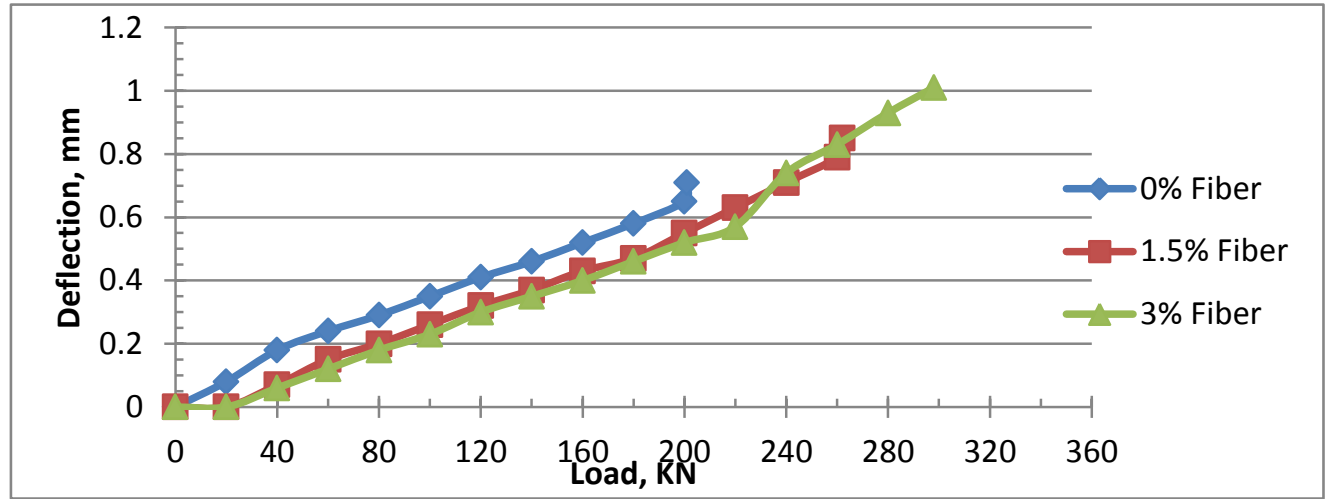

Fig 9: The Graph of Central Deflection with respect to Load, Specimen-II

From Table 4, Fig 9, it is observed that, deflection is directly proportional to fiber content. There is considerable increase in deflection for beam of $3 \%$ fiber content.

\subsection{Calculation Ultimate of Shear Stress}

\subsubsection{Ultimate Shear Stress for Beam Specimen Series-I}

Results of ultimate shear stress for specimen series-I are presented in Table 5 and the comparison of ultimate shear stress of concrete with respect to fiber content is presented in Fig 10.

Table 5: Ultimate Shear Stress for Specimen Series-I, N/mm²

\begin{tabular}{|c|c|c|c|c|c|}
\hline Sr. No. & Beam Designation & $\begin{array}{l}\text { Failure Load } \\
\text { (KN) }\end{array}$ & $\begin{array}{c}\text { Average } \\
\text { Failure Load } \\
(\text { KN) }\end{array}$ & $\begin{array}{l}\text { Ultimate Shear } \\
\text { Stress }\left(\mathbf{N} / \mathbf{m m}^{2}\right)\end{array}$ & $\begin{array}{c}\text { Average } \\
\text { Ultimate Shear } \\
\text { Stress }\left(\mathrm{N} / \mathrm{mm}^{2}\right)\end{array}$ \\
\hline 1. & IB11-0\%-0.60 & 128 & \multirow{3}{*}{132} & 4.309 & \multirow{3}{*}{4.444} \\
\hline 2. & IB12-0\%-0.60 & 131 & & 4.410 & \\
\hline 3. & IB13-0\%-0.60 & 137 & & 4.612 & \\
\hline 4. & IB21-1.5\%-0.60 & 165 & \multirow{3}{*}{170} & 5.555 & \multirow{3}{*}{5.723} \\
\hline 5. & IB22-1.5\%-0.60 & 174 & & 5.858 & \\
\hline 6. & IB23-1.5\%-0.60 & 171 & & 5.757 & \\
\hline 7. & IB31-3\%-0.60 & 189.5 & \multirow{3}{*}{192} & 6.380 & \multirow{3}{*}{6.464} \\
\hline 8. & IB32-3\%-0.60 & 192.5 & & 6.481 & \\
\hline 9. & IB33-3\%-0.60 & 194 & & 6.531 & \\
\hline
\end{tabular}

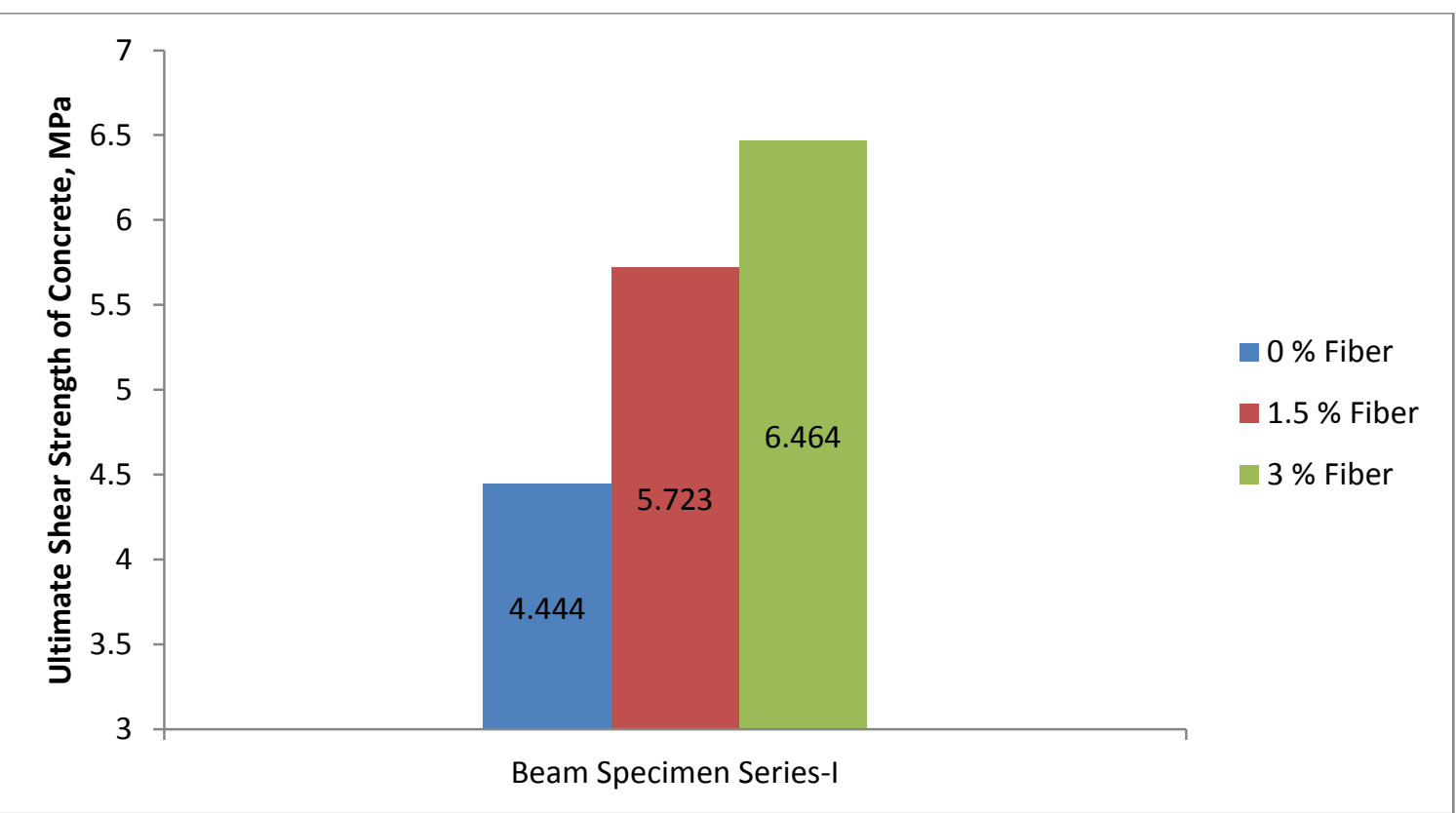

Fig 10: Comparison of Ultimate Shear Stress with respect to Fiber Content 
From Table 5 and Fig 10, the maximum value of ultimate shear stress $6.464 \mathrm{~N} / \mathrm{mm}^{2}$ is

observed at $3 \%$ of fiber content.

\subsubsection{Ultimate Shear Stress for Specimen Series-II}

Results of ultimate shear stress for specimen series-II are presented in Table 6 and the comparison of ultimate shear stress of concrete with respect to fiber content is presented in Fig 11.

Table 6: Ultimate Shear Stress for Specimen Series-II, N/mm²

\begin{tabular}{|c|c|c|c|c|c|}
\hline Sr. No. & Beam Designation & $\begin{array}{c}\text { Failure Load } \\
(\text { KN) }\end{array}$ & $\begin{array}{c}\text { Average } \\
\text { Failure Load } \\
\text { (KN) }\end{array}$ & $\begin{array}{l}\text { Ultimate Shear } \\
\text { Stress }\left(\mathrm{N} / \mathrm{mm}^{2}\right)\end{array}$ & $\begin{array}{c}\text { Average } \\
\text { Ultimate Shear } \\
\text { Stress }\left(\mathrm{N} / \mathrm{mm}^{2}\right)\end{array}$ \\
\hline 1. & IIB'11-0\%-0.74 & 97 & \multirow{3}{*}{100.5} & 3.991 & \multirow{3}{*}{4.135} \\
\hline 2. & IIB'12-0\%-0.74 & 101 & & 4.156 & \\
\hline 3. & IIB'13-0\%-0.74 & 103.5 & & 4.259 & \\
\hline 4. & IIB'21-1.5\%-0.74 & 129 & \multirow{3}{*}{131} & 5.308 & \multirow{3}{*}{5.390} \\
\hline 5. & IIB'22-1.5\%-0.74 & 130 & & 5.349 & \\
\hline 6. & IIB'23-1.5\%-0.74 & 134 & & 5.514 & \\
\hline 7. & IIB'31-3\%-0.74 & 145 & \multirow{3}{*}{149} & 5.967 & \multirow{3}{*}{6.131} \\
\hline 8. & IIB'32-3\%-0.74 & 152 & & 6.255 & \\
\hline 9. & IIB'33-3\%-0.74 & 150 & & 6.172 & \\
\hline
\end{tabular}

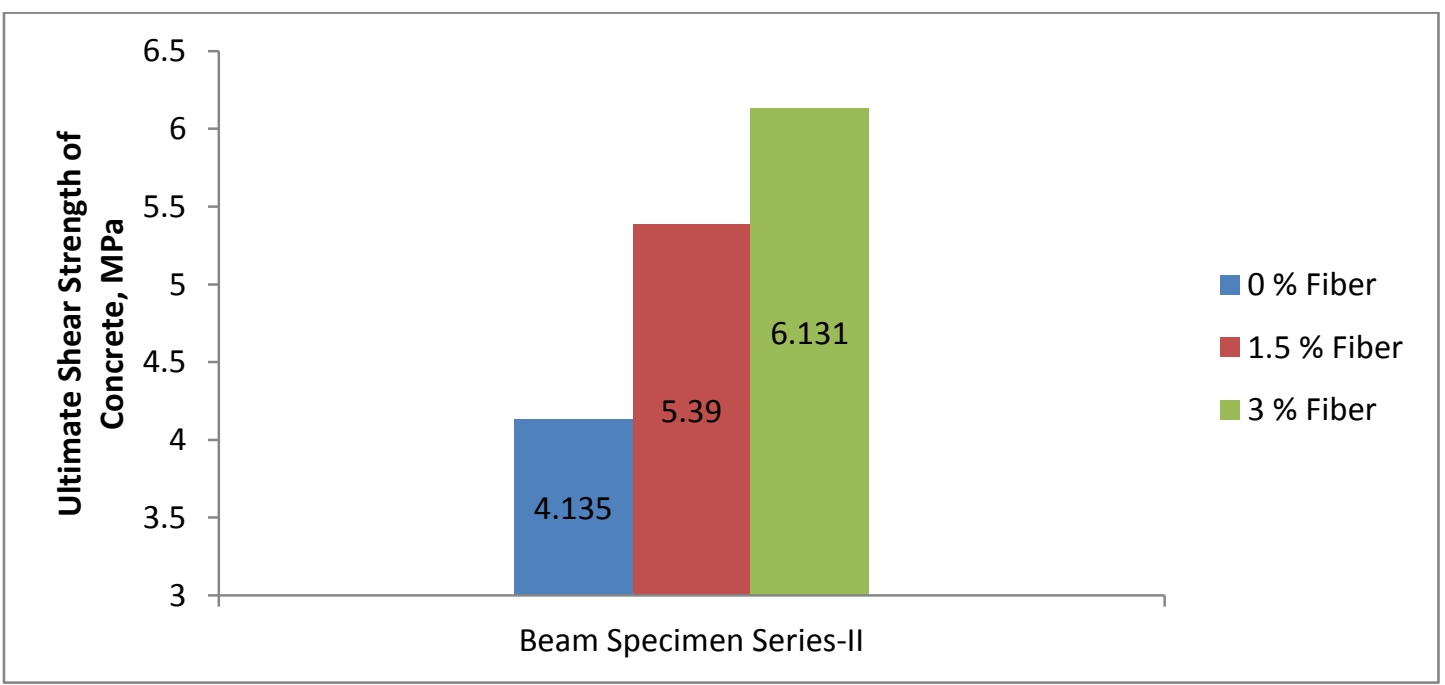

Fig 11: Ultimate Shear Stress of Concrete with respect to Fiber Content

From Table 6 and Fig 11, it is observed the maximum value of ultimate shear stress $6.131 \mathrm{~N} / \mathrm{mm} 2$ is observed at $3 \%$ of fiber content and shear stress increases with increase in fiber content.

\subsubsection{The Ultimate Shear Stress of Concrete with respect to a/d Ratio and \% Fiber Content.}

The ultimate shear stress of concrete with respect to $a / d$ ratio and $\%$ fiber content is presented in Table 7. The comparison of ultimate shear strength of concrete with respect to $a / d$ ratio and percentage fiber content is presented in Fig 12.

Table 7: Ultimate Shear Strength of Concrete with respect to $a / d$ Ratio and \% Fiber Content.

\begin{tabular}{|c|c|c|c|}
\hline $\begin{array}{l}\text { Sr. } \\
\text { No. }\end{array}$ & $\begin{array}{c}\text { Fiber Content } \\
(\%)\end{array}$ & a/d Ratio & $\begin{array}{c}\text { Ultimate Shear Stress } \\
\left(\mathbf{N} / \mathbf{m m}^{2}\right)\end{array}$ \\
\hline 1. & \multirow[t]{2}{*}{ 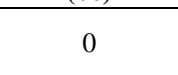 } & 0.60 & 4.444 \\
\hline 2. & & 0.74 & 4.135 \\
\hline 3. & \multirow{2}{*}{1.5} & 0.60 & 5.723 \\
\hline 4. & & 0.74 & 5.390 \\
\hline 5. & \multirow{2}{*}{3} & 0.60 & 6.464 \\
\hline 6. & & 0.74 & 6.131 \\
\hline
\end{tabular}




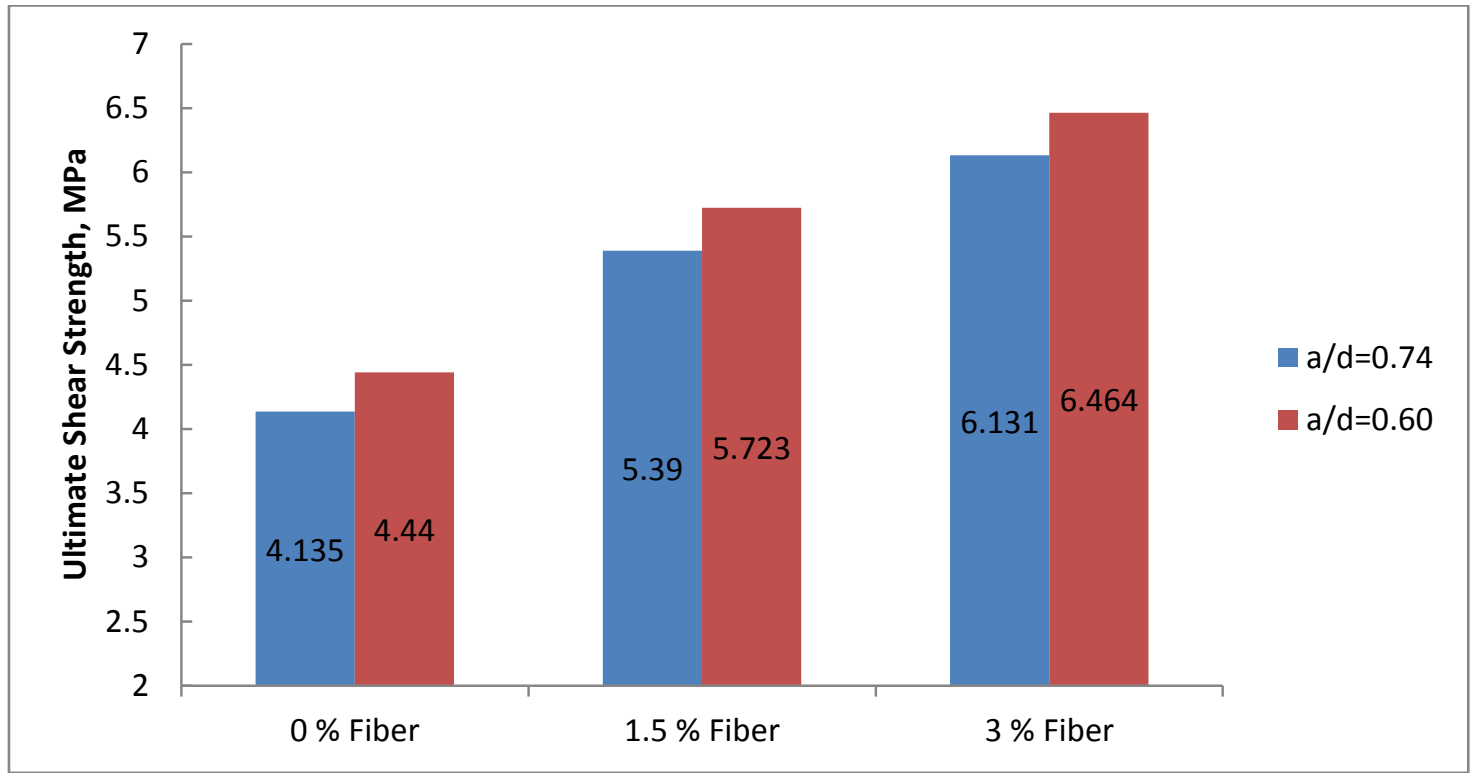

Figure 12: Ultimate Shear Strength of Concrete with respect to $a / d$ Ratio and \% Fiber Content From Table 7 and Fig 12, it is observed that ultimate shear stress is directly proportional to percentage fiber content and inversely proportional to $a / d$ ratio.

\subsubsection{Percentage Increase in Ultimate Shear Stress}

Results of percentage increase in ultimate shear stress are presented in Table 8

Table 8: Percentage Increase in Ultimate Shear Stress, $\mathrm{N} / \mathrm{mm}^{2}$

\begin{tabular}{|c|c|c|c|c|}
\hline Sr. No. & a/d Ratio & $\%$ of Fiber & $\begin{array}{c}\text { Ultimate Shear Stress } \\
\left(\mathbf{N} / \mathbf{m m}^{2}\right)\end{array}$ & $\begin{array}{l}\text { Increase in Ultimate } \\
\text { Shear Stress (\%) }\end{array}$ \\
\hline 1. & \multirow{3}{*}{0.60} & 0 & 4.444 & 0 \\
\hline 2. & & 1.5 & 5.723 & 28.78 \\
\hline 3. & & 3 & 6.464 & 45.45 \\
\hline 4. & \multirow{3}{*}{0.74} & 0 & 4.135 & 0 \\
\hline 5. & & 1.5 & 5.390 & 30.35 \\
\hline 6. & & 3 & 6.131 & 48.27 \\
\hline
\end{tabular}

From Table 8, percentage ultimate shear stress of beam increased with increase of fiber content. Maximum percentage increase in ultimate shear stress is $48.27 \%$.

\subsection{Cracking Shear Stress}

4.6.1 Cracking Shear Stress for Specimen Series-I

Results of cracking shear stress for specimen series-I are presented in Table 9 and the comparison of cracking shear stress with respect to fiber content is presented in Fig 13.

Table 9: Cracking Shear Stress for Specimen Series-I, N/mm²

\begin{tabular}{|c|c|c|c|c|c|}
\hline Sr. No. & Beam Designation & $\begin{array}{l}\text { Load } \\
(\mathbf{K N})\end{array}$ & $\begin{array}{l}\text { Average Load } \\
\text { (KN) }\end{array}$ & $\begin{array}{l}\text { Cracking Shear } \\
\text { Stress }\left(\mathbf{N} / \mathbf{m m}^{2}\right)\end{array}$ & $\begin{array}{c}\text { Average } \\
\text { Cracking Shear } \\
\text { Stress } \\
\left(\mathbf{N} / \mathbf{m m}^{2}\right) \\
\end{array}$ \\
\hline 1. & IB11-0\%-0.60 & 88 & \multirow{3}{*}{92} & 2.962 & \multirow{3}{*}{3.097} \\
\hline 2. & IB12-0\%-0.60 & 95 & & 3.198 & \\
\hline 3. & IB13-0\%-0.60 & 93 & & 3.131 & \\
\hline 4. & IB21-1.5\%-0.60 & 107.5 & \multirow{3}{*}{111} & 3.619 & \multirow{3}{*}{3.737} \\
\hline 5. & IB22-1.5\%-0.60 & 112 & & 3.771 & \\
\hline 6. & IB23-1.5\%-0.60 & 113.5 & & 3.821 & \\
\hline 7. & IB31-3\%-0.60 & 121 & \multirow{3}{*}{121.5} & 4.074 & \multirow{3}{*}{4.090} \\
\hline 8. & IB32-3\%-0.60 & 124 & & 4.175 & \\
\hline 9. & IB33-3\%-0.60 & 119.5 & & 4.023 & \\
\hline
\end{tabular}




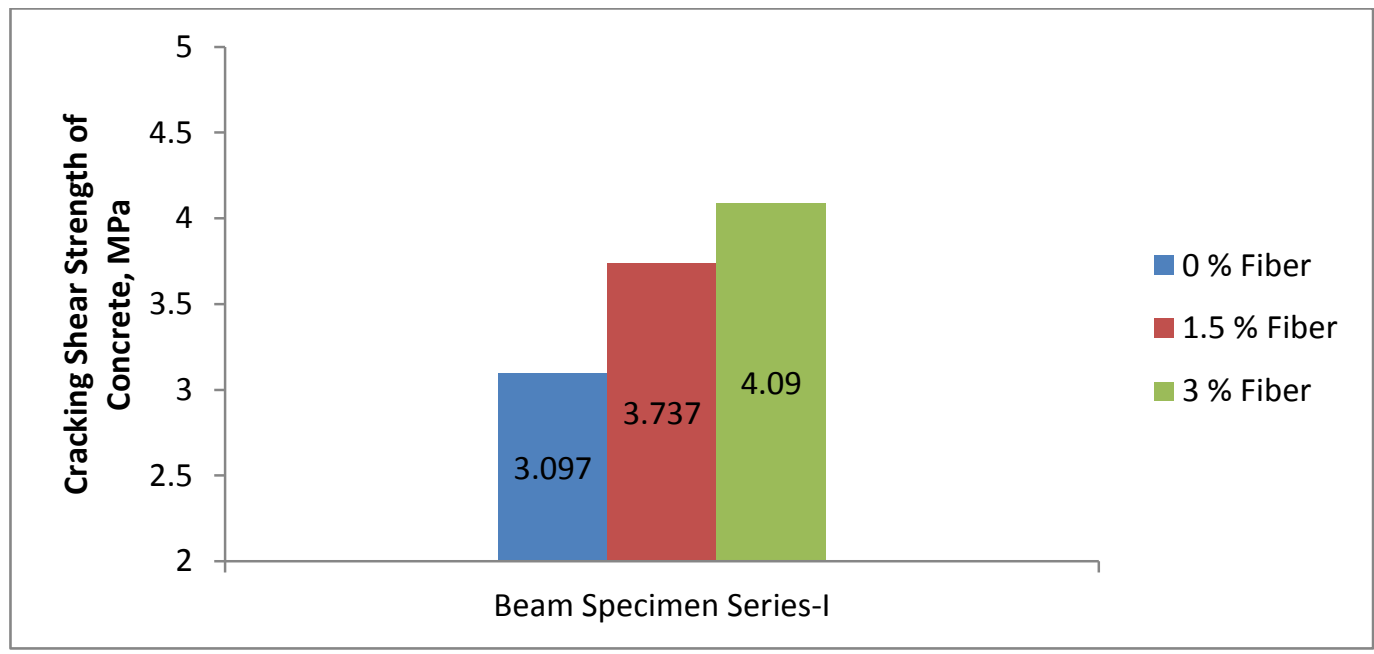

Fig 13: Cracking Shear Stress with respect to Fiber Content

From Table 9 and Fig 13, it is observed that, the maximum value of cracking shear stress $4.09 \mathrm{~N} / \mathrm{mm}^{2}$ is observed at $3 \%$ of fiber content and cracking shear stress is directly proportional to \% fiber content.

\subsubsection{Cracking Shear Stress for Specimen Series-II}

Results of cracking shear stress for specimen series-II are presented in Table 10 and the comparison of cracking shear stress of concrete with respect to \% fiber content is presented in Fig 14.

Table 10: Cracking Shear Stress for Specimen Series-II, N/mm ${ }^{2}$

\begin{tabular}{|c|c|c|c|c|c|}
\hline Sr. No. & Beam Designation & $\begin{array}{l}\text { Load } \\
(\mathbf{K N})\end{array}$ & $\begin{array}{c}\text { Average } \\
\text { Failure load } \\
(\text { KN) }\end{array}$ & $\begin{array}{c}\text { Cracking } \\
\text { Shear Stress } \\
\left(\mathbf{N} / \mathbf{m m}^{2}\right)\end{array}$ & $\begin{array}{c}\text { Average } \\
\text { Cracking } \\
\text { Shear Stress } \\
\left(\mathbf{N} / \mathbf{m m}^{2}\right)\end{array}$ \\
\hline 1. & IIB'11-0\%-0.74 & 72 & \multirow{3}{*}{69} & 2.962 & \multirow{3}{*}{2.839} \\
\hline 2. & IIB'12-0\%-0.74 & 65 & & 2.674 & \\
\hline 3. & IIB'13-0\%-0.74 & 70 & & 2.880 & \\
\hline 4. & IIB'21-1.5\%-0.74 & 89 & \multirow{3}{*}{86.5} & 3.662 & \multirow{3}{*}{3.559} \\
\hline 5. & IIB'22-1.5\%-0.74 & 84.5 & & 3.477 & \\
\hline 6. & IIB'23-1.5\%-0.74 & 86 & & 3.539 & \\
\hline 7. & IIB'31-3\%-0.74 & 91 & \multirow{3}{*}{93} & 3.744 & \multirow{3}{*}{3.827} \\
\hline 8. & IIB'32-3\%-0.74 & 95 & & 3.909 & \\
\hline 9. & IIB'33-3\%-0.74 & 92 & & 3.786 & \\
\hline
\end{tabular}

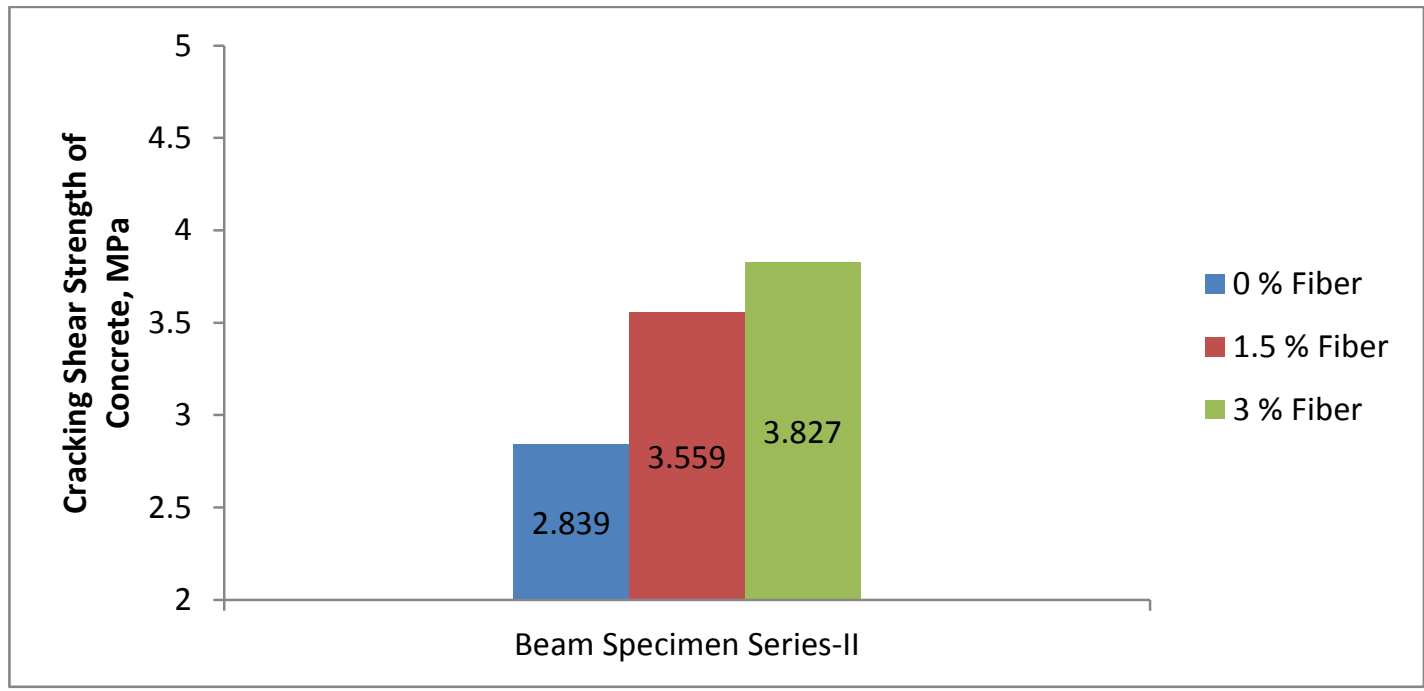

Fig 14: Cracking Shear Stress of Concrete with respect to \% Fiber Content

From Table 4.10 and Figure 14, the maximum value of cracking shear stress $3.827 \mathrm{~N} / \mathrm{mm}^{2}$ is observed at $3 \%$ of fiber content. 


\subsubsection{Cracking Shear Stress of Concrete with respect to a/d Ratio and Percentage Fiber Content}

Cracking shear stress of concrete with respect to $a / d$ ratio and percentage fiber content is presented in Table 11. The comparison of cracking shear stress of concrete with respect to $a / d$ ratio and percentage fiber content is presented in Fig 15.

Table 11: Cracking Shear Stress of Concrete with respect to $a / d$ Ratio and Percentage Fiber Content, $\mathrm{N} / \mathrm{mm}^{2}$

\begin{tabular}{|c|c|c|c|}
\hline Sr. No. & $\begin{array}{c}\text { Fiber Content } \\
(\boldsymbol{\%})\end{array}$ & $\boldsymbol{a} / \boldsymbol{d}$ Ratio & $\begin{array}{c}\text { Cracking Shear Stress } \\
\left(\mathbf{N} / \mathbf{m m}^{\mathbf{2}}\right)\end{array}$ \\
\hline 1. & \multirow{2}{*}{0} & 0.60 & 3.097 \\
\hline 2. & \multirow{2}{*}{1.5} & 0.74 & 2.839 \\
\hline 3. & \multirow{2}{*}{3} & 0.60 & 3.737 \\
\hline 4. & \multirow{2nyy}{nnyy}{} & 0.74 & 3.559 \\
\hline 5. & & 0.60 & 4.090 \\
\hline 6. & & 0.74 & 3.827 \\
\hline
\end{tabular}

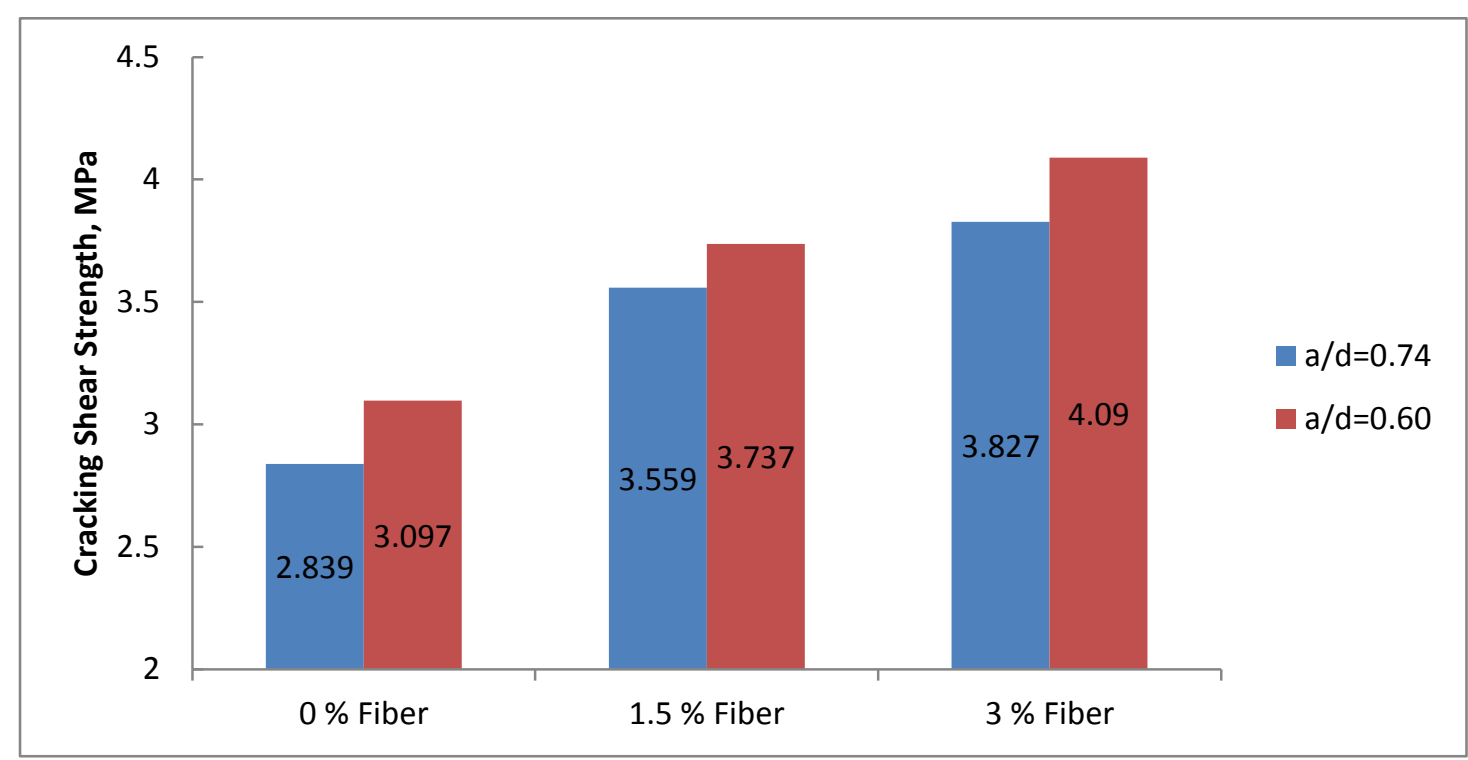

Fig 15: Cracking Shear Stress of Concrete with respect to a/d Ratio and \% Fiber Content

From Table 11 and Fig 15, it is observed that cracking shear stress is directly proportional to percentage fiber content and inversely proportional to $a / d$ ratio.

\subsubsection{Percentage Increase in Cracking Shear Stress}

Results of percentage increase of cracking shear stress are presented in Table 12.

\begin{tabular}{|c|c|c|c|c|}
\hline Sr. No. & a/d Ratio & $\begin{array}{c}\text { Fiber Content } \\
(\%)\end{array}$ & $\begin{array}{l}\text { Cracking Shear } \\
\text { Stress }\left(\mathbf{N} / \mathbf{m m}^{2}\right)\end{array}$ & $\begin{array}{c}\text { Increase in } \\
\text { Cracking Shear } \\
\text { Stress (\%) }\end{array}$ \\
\hline 1. & \multirow{3}{*}{0.60} & 0 & 3.097 & 0 \\
\hline 2. & & 1.5 & 3.737 & 20.66 \\
\hline 3. & & 3 & 4.090 & 32.06 \\
\hline 4. & \multirow{3}{*}{0.74} & 0 & 2.839 & 0 \\
\hline 5. & & 1.5 & 3.559 & 25.36 \\
\hline 6. & & 3 & 3.827 & 34.80 \\
\hline
\end{tabular}

From Table 12, cracking shear stress of beam increases with increase in fiber content, but decrease with respect to increase in $a / d$ ratio. The percentage maximum value of cracking shear stress is 34.80 .

\subsection{Calculation of Shear Strength by Different Shear Design Models}

Six design models, namely, ACI Code 318-05, UK's CIRIA Guide-2, Draft Eurocode-2 (CEB-FIP Model Code), equation of Londhe, equation of Mansur et al. and equation of Khuntia et al. are used to estimate the ultimate shear strength of the deep beam specimens. 


\subsubsection{Evaluation of ACI 318 [30] Shear Design Equation (2005)}

Table 13: Calculation of Shear Strength by ACI 318-05 Design Code, KN

\begin{tabular}{|c|c|c|c|c|c|c|c|}
\hline \multicolumn{8}{|c|}{$V_{c}=\left(3.5-2.5 \frac{M_{u}}{V_{u}}\right)\left(0.16 \sqrt{f^{\prime}}{ }_{c}+17 \rho \frac{V_{u} \mathrm{~d}}{M_{u}}\right) \mathrm{bd}, \rho=0.021, \mathrm{~b}=90$} \\
\hline Sr. No. & Beam Designation & $M u$ & $V u$ & d & $V_{A C I}$ & $V_{T E S T}$ & $V_{T E S T} / V_{A C I}$ \\
\hline 1 & IB- $0 \%-0.60$ & 26.4 & 132 & 330 & 99.636 & 132 & 1.324 \\
\hline 2 & IB-1.5\%-0.60 & 34 & 170 & 330 & 101.682 & 170 & 1.671 \\
\hline 3 & IB-3\%-0.60 & 38.4 & 192 & 330 & 102.536 & 192 & 1.872 \\
\hline 4 & IIB-0\%-0.74 & 20.1 & 100.5 & 270 & 63.615 & 100.5 & 1.579 \\
\hline 5 & IIB- $1.5 \%-0.74$ & 26.2 & 131 & 270 & 64.998 & 131 & 2.015 \\
\hline 6 & IIB-3\%-0.74 & 29.8 & 149 & 270 & 65.192 & 149 & 2.285 \\
\hline & & & & & & & 1.791 \\
\hline
\end{tabular}

\subsubsection{Evaluation of Mansur et al. [2] Equation (1986)}

Table 14: Calculation of Shear Strength by Mansur's Equation, KN

\begin{tabular}{|r|c|c|c|c|c|c|c|}
\hline \multicolumn{7}{|c|}{$V_{f r c}=\left(0.16 \sqrt{f^{\prime} c}+17.2 \rho \frac{\mathrm{d}}{\mathrm{a}}+0.41 \tau \mathrm{F}\right) \mathrm{bd}, \rho=0.021, \tau=0.66 \sqrt{f^{\prime} c}, \mathrm{~F}=V_{f} \frac{l_{f}}{d_{f}}$} \\
\hline Sr. No. & Beam Designation & $\boldsymbol{f}^{\prime} \boldsymbol{c}$ & $\mathbf{F}$ & $\frac{\mathbf{d}}{\mathbf{a}}$ & $V_{\text {MANSUR }}$ & $\boldsymbol{V}_{\text {TEST }}$ & $\boldsymbol{V}_{\text {TEST }} / V_{\text {MANSUR }}$ \\
\hline 1 & IB-0\%-0.60 & 46.99 & 0 & 1.65 & 50.406 & 132 & 2.618 \\
\hline 2 & IB-1.5\%-0.60 & 50.01 & 0.9 & 1.65 & 102.58 & 170 & 1.657 \\
\hline 3 & IB-3\%-0.60 & 51.30 & 1.8 & 1.65 & 155.48 & 192 & 1.234 \\
\hline 4 & IIB-0\%-0.74 & 47.42 & 0 & 1.35 & 38.73 & 100.5 & 2.594 \\
\hline 5 & IIB-1.5\%-0.74 & 50.44 & 0.9 & 1.35 & 81.60 & 131 & 1.605 \\
\hline 6 & IIB-3\%-0.74 & 50.87 & 1.8 & 1.35 & 124.11 & 149 & 1.200 \\
\hline
\end{tabular}

\subsubsection{Evaluation of Ciria Guide-2 [32] Design Equation (1977)}

Table 15: Calculation Shear Strength by Ciria Guide-2 Design Equation, KN

\begin{tabular}{|c|c|c|c|c|c|c|c|}
\hline \multicolumn{8}{|c|}{$V_{c}=\lambda\left[\left(1-0.30 \frac{\mathrm{a}}{\mathrm{d}}\right) \sqrt{f_{c u}} \mathrm{bd}\right], \lambda=0.44$} \\
\hline $\begin{array}{l}\text { Sr. } \\
\text { No. }\end{array}$ & Beam Designation & $f_{c u}$ & D & $\frac{a}{d}$ & $V_{\text {CIRIA }}$ & $V_{T E S T}$ & $V_{\text {TEST }} / V_{\text {CIRIA }}$ \\
\hline 1 & IB-0\%-0.60 & 46.99 & 330 & 0.60 & 70.578 & 132 & 1.870 \\
\hline 2 & IB- $1.5 \%-0.60$ & 50.01 & 330 & 0.60 & 72.810 & 170 & 2.334 \\
\hline 3 & IB-3\%-0.60 & 51.30 & 330 & 0.60 & 73.744 & 192 & 2.603 \\
\hline 4 & IIB-0\%-0.74 & 47.42 & 270 & 0.74 & 54.538 & 100.5 & 1.842 \\
\hline 5 & IIB- $1.5 \%-0.74$ & 50.44 & 270 & 0.74 & 56.248 & 131 & 2.328 \\
\hline 6 & IIB-3\%-0.74 & 50.87 & 270 & 0.74 & 56.487 & 149 & 2.637 \\
\hline & & & & & & & 2.269 \\
\hline
\end{tabular}

\subsubsection{Evaluation of Londhe's [22] Design Equation (2011)}

Table 16: Calculation of Shear Strength by Londhe's Equation, KN

\begin{tabular}{|r|c|c|c|c|c|c|c|}
\hline \multicolumn{7}{|c|}{$V_{c}=\alpha\left[\left(1-0.30 \frac{\mathrm{a}}{\mathrm{d}}\right) \sqrt{0.80 f_{\text {ck }}} \mathrm{bd}\right], \alpha=0.35$} \\
\hline $\begin{array}{c}\text { Sr. } \\
\text { No. }\end{array}$ & Beam Designation & $\boldsymbol{f}_{\boldsymbol{c k}}$ & $\frac{\mathbf{a}}{\mathbf{d}}$ & $\mathbf{d}$ & $\boldsymbol{V}_{\text {LONDHE }}$ & $\boldsymbol{V}_{\text {TEST }}$ & $\boldsymbol{V}_{\text {TEST }} / \boldsymbol{V}_{\text {LONDHE }}$ \\
\hline 1 & IB-0\%-0.60 & 46.99 & 0.60 & 330 & 62.575 & 132 & 2.109 \\
\hline 2 & IB-1.5\%-0.60 & 50.01 & 0.60 & 330 & 64.554 & 170 & 2.633 \\
\hline 3 & IB-3\%-0.60 & 51.30 & 0.60 & 330 & 65.382 & 192 & 2.936 \\
\hline 4 & IIB-0\%-0.74 & 47.42 & 0.74 & 270 & 48.891 & 100.5 & 2.055 \\
\hline 5 & IIB-1.5\%-0.74 & 50.44 & 0.74 & 270 & 50.424 & 131 & 2.597 \\
\hline 6 & IIB-3\%-0.74 & 50.87 & 0.74 & 270 & 50.639 & 149 & 2.942 \\
\hline
\end{tabular}




\subsubsection{Evaluation of Khuntia et al. [16] Equation (1999)}

Table 17: Calculation of Shear Strength by Khuntia's Equation, KN

\begin{tabular}{|r|c|c|c|c|c|c|c|}
\hline \multicolumn{8}{|c|}{$V_{f r c}=\left(0.167 \alpha_{1}+0.25 \mathrm{~F}\right) \sqrt{f^{\prime} c}$ bd, $\alpha_{1}=2.5 \frac{d}{a}, \mathrm{~F}=V_{f} \frac{l_{f}}{d_{f}}$} \\
\hline $\begin{array}{c}\text { Sr. } \\
\text { No. }\end{array}$ & Beam Designation & $\boldsymbol{f}^{\prime}{ }_{\boldsymbol{c}}$ & $\frac{\mathbf{a}}{\mathbf{d}}$ & $\mathbf{d}$ & $\boldsymbol{V}_{\text {KHUNTIA }}$ & $\boldsymbol{V}_{\text {TEST }}$ & $\boldsymbol{V}_{\text {TEST }} / \boldsymbol{V}_{\text {KHUNTIA }}$ \\
\hline 1 & IB-0\%-0.60 & 46.99 & 0.60 & 330 & 140.248 & 132 & 0.941 \\
\hline 2 & IB-1.5\%-0.60 & 50.01 & 0.60 & 330 & 191.942 & 170 & 0.885 \\
\hline 3 & IB-3\%-0.60 & 51.30 & 0.60 & 330 & 242.265 & 192 & 0.792 \\
\hline 4 & IIB-0\%-0.74 & 47.42 & 0.74 & 270 & 94.314 & 100.5 & 1.065 \\
\hline 5 & IIB-1.5\%-0.74 & 50.44 & 0.74 & 270 & 136.102 & 131 & 0.962 \\
\hline 6 & IIB-3\%-0.74 & 50.87 & 0.74 & 270 & 175.676 & 149 & 0.848 \\
\hline
\end{tabular}

\subsubsection{Evaluation of Draft Eurocode-2 [31] Design Equation (2004)}

Table 18: Calculation of Shear Strength by Draft Eurocode-2 Equation, KN

\begin{tabular}{|r|c|c|c|c|c|c|}
\hline \multicolumn{7}{|c|}{$V_{c}=0.10 \mathrm{bD}\left(\frac{f^{\prime}}{\gamma_{m}}\right), \gamma_{m}=1.5$} \\
\hline Sr. No. & Beam Designation & $\boldsymbol{f}^{\prime}{ }_{\boldsymbol{c}}$ & $\mathbf{D}$ & $\boldsymbol{V}_{\text {EUROCODE }}$ & $\boldsymbol{V}_{\text {TEST }}$ & $\boldsymbol{V}_{\text {TEST }} \boldsymbol{V}_{\text {EUROCODE }}$ \\
\hline 1 & IB-0\%-0.60 & 46.99 & 360 & 101.498 & 132 & 1.300 \\
\hline 2 & IB-1.5\%-0.60 & 50.01 & 360 & 108.021 & 170 & 1.573 \\
\hline 3 & IB-3\%-0.60 & 51.30 & 360 & 110.808 & 192 & 1.732 \\
\hline 4 & IIB-0\%-0.74 & 47.42 & 330 & 93.891 & 100.5 & 1.070 \\
\hline 5 & IIB-1.5\%-0.74 & 50.44 & 330 & 99.871 & 131 & 1.311 \\
\hline 6 & IIB-3\%-0.74 & 50.87 & 330 & 100.742 & 149 & 1.479 \\
\hline \multicolumn{7}{|l|}{} \\
\hline
\end{tabular}

\subsection{Summary Test}

Table 19: Comparison Equation with respect to Mean Value of $V_{T E S T} / V_{E Q U A T I O N}$

\begin{tabular}{|c|c|c|}
\hline Reference & Equation & $\begin{array}{c}\text { Mean } \\
V_{T E S T} / V_{\text {EQUATION }}\end{array}$ \\
\hline ACI 318(2005) & $V_{c}=\left(3.5-2.5 \frac{M_{u}}{V_{u}}\right)\left(0.16 \sqrt{f^{\prime}{ }_{c}}+17 \rho \frac{V_{u} \mathrm{~d}}{M_{u}}\right) \mathrm{bd}$ & 1.791 \\
\hline Mansur et al. $(1986)$ & $V_{f r c}=\left(0.16 \sqrt{f^{\prime} c}+17.2 \rho \frac{\mathrm{d}}{\mathrm{a}}+0.41 \tau \mathrm{F}\right) \mathrm{bd}$ & 1.818 \\
\hline Ciria Guide-2 (1977) & $V_{c}=\lambda\left[\left(1-0.30 \frac{\mathrm{a}}{\mathrm{d}}\right) \sqrt{f_{c u}} \mathrm{bd}\right]$ & 2.269 \\
\hline Londhe $(2011)$ & $V_{c}=\alpha\left[\left(1-0.30 \frac{\mathrm{a}}{\mathrm{d}}\right) \sqrt{0.80 f_{c k}} \mathrm{bd}\right]$ & 2.545 \\
\hline Khuntia et al. $(1999)$ & $V_{f r c}=\left(0.167 \alpha_{1}+0.25 \mathrm{~F}\right) \sqrt{f^{\prime} c} \mathrm{bd}$ & 0.915 \\
\hline $\begin{array}{c}\text { Draft Eurocode } \\
\text { (2004) }\end{array}$ & $V_{c}=0.10 \mathrm{bD}\left(\frac{f^{\prime}}{\gamma_{m}}\right)$ & 1.410 \\
\hline
\end{tabular}

From Table 19, it is observed that the equation proposed by Draft Eurocode gives good results for shear strength of concrete deep beams without fibers as compared to the equations proposed by other codes and researchers. The equation proposed by Mansur et al. gives good results for shear strength of steel fiber reinforced concrete deep beams. Also the results given by ACI 318-05 Code are satisfactory. The results given by Ciria Guide-2 and Londhe's equation are on higher sides.

\section{CONCLUSION}

This chapter presents the major conclusions and future scope of the investigation to determine the shear strength of SFRC deep beams. Based on the test results and verification with other authors following conclusions can be drawn.

1. The inclusion of short steel fibers in concrete mix provides effective shear reinforcement in deep beams.

2. Steel fibers in concrete deep beams provides better crack control and deformation characteristic of beams. 
3. Both the first crack strength and ultimate strength in shear increase with increase in fiber content because of their increased resistance to propagation of cracks.

4. The addition of steel fibers increases the compressive strength of concrete. However, there is not much more increase in compressive strength of concrete content $3 \%$ fiber as compared with compressive strength of concrete content $1.5 \%$ fiber.

5. The cracking shear strength and ultimate shear strength increases with increasing percent fiber content and decreasing $a / d$ ratio.

6. Maximum increase of $48.27 \% t$ in ultimate load for beam containing $3 \%$ fibers was observed when compared with beam containing no fiber.

7. Maximum increase of $34.80 \%$ in first cracking load for beam containing $3 \%$ fibers was observed when compared with beam containing no fiber.

8. The equation proposed by Draft Eurocode gives good results for shear strength of concrete deep beams without fibers.

9. The equation proposed by Mansur et al. gives good results for shear strength of steel fiber reinforced concrete deep beams. This equation seems to be appropriate to estimate shear strength of normal strength concrete to high strength concrete, which shows the uniqueness of this equation. Thus, it can be proposed to include this equation in design codes of practice in case of fiber reinforced concrete beam.

\section{Acknowledgements}

This is to acknowledge \& thank all the individuals who played defining role in shaping my project. Without their consent support, guidance \& assistance this project would not have been completed. I acknowledge with thanks, the guidance \& generous help rendered by my Project guide C.R.Nayak \& Co-guide Prof S.B.Walke, for their valuable guidance, continual encouragement \& advice. I think without their humble support it won't be possible.

I am also thankful to Prof G.N.Narule, the Professor \& Head of the Department of Civil Engineering for supporting as $\&$ when required for their valuable suggestions $\&$ advice during project work.

\section{REFERENCES}

[1] T. M. Roberts and N. L. Ho (1982), "Shear Failure of Deep Fibre Reinforced Concrete", The International Journal of Cement Composites and Lightweight Concrete, Vol. 4, pp. 145-152.

[2] M. A. Mansur, K. C. G. Ong and P. Paramasivam (1986), "Shear Strength of Fibrous Concrete Beams without Stirrups", Journal of Structural Engineering, ASCE, Vol. 112(9), pp. 2066-2079.

[3] S. K. Madan, G. R. Kumar and S. P. Singh (2007), "Steel Fibers as Replacement of Web Reinforcement for RCC Deep Beams in Shear", Asian Journal of Civil Engineering, Vol. 8(5), pp. 479-489.

[4] W. Y. Lu (2006), "Shear Strength Prediction for Steel Reinforced Concrete Deep Beams", Journal of Constructional Steel Research, Vol. 62, pp. 933-942.

[5] M. S. Alam, E. Slater and M. Moni (2012), "Predicting the Shear Strength of Steel Fiber Reinforced Concrete Beams", Construction of Building Materials, Vol. 26, pp. 423-436.

[6] V. Vengatachalapathy (2010), "Behavior and Ultimate Strength of Steel Fiber Reinforced Concrete (SFRC) Deep Beams with and without Openings", International Journal of Civil and Structural Engineering, Vol. 1(3), pp. 509-517.

[7] H. H. Dinh, G. J. Parramontesinos, and J. K. Wight (2011), "Shear Behavior of Steel Fiber Reinforced Concrete Beams without Stirrup Reinforcement", Journal of Structural Engineering, ASCE, Vol. 137(10), pp. 10.39-1051.

[8] R. S. Londhe (2009), "Experimental Study of Shear Strength of Concrete Beams Reinforced with Longitudinal Tension Steel", Asian Journal of Civil Engineering and Housing, Vol. 10(3), pp. 257-264.

[9] K. H. Tan and M. A. Mansur (1990), "Shear Transfer in Fiber Reinforced Concrete", Journal of Structural Engineering, ASCE, Vol. 2(4), pp. 202-214.

[10] J. Susetyo, P. Gauvreau, and F. Vecchio (2011), "Effectiveness of Steel Fiber as Minimum Shear Reinforcement", ACI Structural Journal, Vol. 108(4), pp. 488-496.

[11] Y. K. Kwak, W. S. Kim and J. kim (2002), "Shear Strength Steel Fiber Reinforced Concrete Deep Beams without Stirrups", ACI Structural Journal, Vol. 99(4), pp. 530-538.

[12] R. Narayanan and I. Y. S. Darwish (1987), "Use of Steel Fibers as Shear Reinforcement", ACI Structural Journal, Vol. 84(3), pp. 216-227.

[13] R. N. Swamy and H. M Bahia (1985), "Effectiveness of Steel Fibers as Shear Reinforcement", Concrete International: Design and Construction, Vol. 7(3), pp. 35-40.

[14] A. A. Mirsayah and N. Banthia (2002), "Shear Strength of Steel Fiber-Reinforced Concrete", ACI Materials Journal, Vol. 99(5), pp. 473-479.

[15] P. Y. Pawade, P. B. Nagarnaik and A. M. Pande (2011), "Performance of Steel Fiber on Standard Strength Concrete in Compression", International Journal of Civil and Structural Engineering, Vol. 2(2), pp. 483-492.

[16] M. Khuntia, S. Bozidar and S. C. Goel (1999), "Shear Strength of Normal and High Strength Fiber Reinforced Concrete Beams without Stirrups", ACI Structural Journal, Vol. 96(2), pp. 282-290.

[17] V. R. Patel and I. I. Pandya (2010), "Evaluation of Shear Strength of SFRC Moderate Deep Beams using Strut-and-Tie Models", International Journal of Modern Engineering Research, Vol. 1, pp. 15-20.

[18] J. Y. Lee and U. Y. Kim (2008), "Effect of Longitudinal Tensile Reinforcement Ratio and a/d Ratio on Minimum Shear Reinforcement in Beam", ACI Structural Journal, Vol. 105(2), pp. 134-144.

[19] K. H. Yang and A. F. Ashour (2008), "Effectiveness of Web Reinforcement around Openings in Continuous Concrete Deep Beams", ACI Structural Journal, Vol. 105(4), pp. 414-424. 
[20] B. Singh and S. K. Kaushik (2006), "Design of Continuous Deep Beam using Strut-and-Tie Method", Asian Journal of Civil Engineering, Vol. 7(5), pp. 461-477.

[21] G. Aguilar, A. B. Matomoros and J. Gustavo (2002), "Experimental Evaluation of Design Procedures for Shear Strength of Deep Reinforced Concrete Beams", ACI Structural Journal, Vol. 99(4), pp. 539-54.

[22] R. S. Londhe (2011), "Shear Strength Analysis and Prediction of Reinforced Concrete Transfer Beams in High Rise Buildings", Structural Engineering and Mechanics, Vol. 37(1), pp. 39-59.

[23] H. Yakoub (2011), "Shear Stress Prediction: Steel Fiber-Reinforced Concrete Beams without Stirrups", ACI Structural Journal, Vol. 108(3), pp. 304-314.

[24] Y. Ding and Zhiguo (2011), "The Composite Effect of Steel Fibres and Stirrups on the Shear Behavior of Beams using SelfConsolidating Concrete", Engineering Structures, Vol. 33, pp. 107-117.

[25] H. H. Dinh, J. K. Wight (2010), "Shear Behavior of Steel Fiber Reinforced Concrete Beams without Stirrup Reinforcement", ACI Structural Journal, Vol. 107(5), pp. 597-606.

[26] K. Noghabai (2000), "Beams of Fibrous Concrete in Shear and Bending: Experiment and Model", Journal of Structural Engineering, ASCE, Vol. 126(2), pp. 243-251.

[27] K. H. Yang (2003). "Shear Characteristics of High-Strength Concrete Deep Beams without Shear Reinforcements", Engineering Structures, Vol. 25, pp. 1343-1352.

[28] ACI Committee 318 (2005), "Building Code Requirements for Structural Concrete and Commentary (ACI 318R-05)", American Concrete Committee, Farminton Hills, USA.

[29] CIRIA Guide-2 (1977), "The Design of Deep Beams in Reinforced Concrete, Ove Arup and Partners", Construction Industry Research and Information Association, London.

[30] Eurocode 2 (2004), "Design of Concrete Structure", British Standard Institution.

[31] IS 456 (2000), "Indian Standard Code of Practice for Plain and Reinforced Concrete, (fourth Revision)", Bureau of Indian Standard, New Delhi, India.

[32] IS 10262 (2009), "Indian Standard Recommended Guidelines for Concrete Mix Design", Bureau of Indian Standard, New Delhi, India. 